\title{
Are IFRS Harder to Implement for Emerging Economies Compared to Developed Countries? A Literature Review
}

\author{
Raoudha Trabelsi \\ Sfax University, Sfax, Tunisia
}

\begin{abstract}
In practice, the international accounting harmonization process faces cultural resistance in the concrete situations of accounting reforms. We often tend to believe that this resistance is felt more in the so-called emerging countries, rather than the developed ones. It is precisely this idea that the paper attempts to analyze, based on a literature review. The literature shows that emerging countries do not have the infrastructure or the real needs justifying a reform of international harmonization, except the need to display an IFRS label (Daske, Hail, Leuz, \& Verdi, 2007), to facilitate the access of firms from emerging economies to developed financial markets. Moreover, the Anglo-American culture attached to IFRS leads to a difficulty in adopting those standards by any country whose original accounting system is continental. Indeed, for these countries, the process of international harmonization begins with an adaptation to the Anglo-Saxon accounting culture, the latter being different from the continental accounting culture at several levels.
\end{abstract}

Keywords: international accounting harmonization, IFRS, emerging countries, accounting culture

\section{Introduction}

The adoption of IFRS has evolved considerably in the world. Several countries have chosen to impose to their companies to apply IFRS for their financial reporting in the near future. Moreover, even before the IFRS adoption becomes mandatory, many companies around the world had already voluntarily switched to those standards (Pourtier, 2004). The European Union (EU) decided in 2002 to adopt international accounting standards by the European Regulation (EC) No. 1606/2002 and implemented the standards starting from January 1, 2005 for European companies making public offerings and publishing consolidated financial statements, and starting from January 1, 2007 for companies with only listed securities other than shares.

However, the choice of accounting harmonization has not, to date, touched all the countries of the world. Indeed, despite the universal consciousness of the challenges of such a globalist action, several countries remain reluctant and are still applying their local accounting standards to their economic entities.

Moreover, in practice, the harmonization process faces cultural resistance in the concrete situations of accounting reforms. We often tend to believe that this resistance is felt more in the so-called emerging countries, rather than the developed ones. It is precisely this idea that the paper attempts to analyze, based on a literature review.

Raoudha Trabelsi, assistant professor, Sfax Business School, Sfax University. Email: raoudha.trabelsi@gmail.com. 


\section{IFRS Would be Hard/Easy to Implement According to the Nature of the Country (Emerging vs. Developed)...}

According to several authors, the process of transition to IFRS is often more complex in some countries of the world, so-called emerging or developing. Moreover, the most general finding is that the pioneers of adopting IFRS are mostly developed countries.

Actually, among the countries that adopted IFRS, several countries reserve this reform to a particular category of firms that meet specific characteristics, and allow other companies, the smallest, to apply the country's local standards. Moreover, according to the Intergovernmental Working Group of Experts on International Standards of Accounting and Reporting (ISAR) whose main objective is the improvement of accounting information, SMEs requirements regarding accounting standards are quite different from those of big firms and multinational corporations. In fact, those international standards, basically intended to be universally applied, have untested implementing rules that do not face the reality of SMEs. This being, as SMEs constitute a large part of the economic environment of emerging countries, IFRS are less relevant for such countries.

In fact, the integration of developing markets in the new international accounting harmonization is a topic of discussion since the creation of the International Accounting Standards Committee (IASC), the predecessor of the International Accounting Standards Board (IASB). The latter has already addressed the issue of whether developing markets should have their own international accounting system to conclude that it was better not to make a distinction (Fouda, 2006). Most public and private companies in developing markets are unlisted small- and medium-sized enterprises (SMEs). Therefore, according to the IASB, smaller companies need to adopt a different accounting treatment whether they belong to developed or developing countries. Thus, the IASB has put aside issues related to developing markets (Fouda, 2006). Moreover, the organism itself admits that "the issue of developing markets is just not a part of the IASB's priorities".

But, the universal vocation of accounting is supposed to exist and grow, basically by bringing together the basic concepts including both types of countries. According to Jean Hegarty, Director of Financial Management for the region of Europe and Central Asia at the World Bank and Chairman of the Bank's Financial Sector Committee based in Washington, this merger lies mainly with standardization bodies; the aim is to define international standards that would make comparable national accounting systems, without underestimating the importance of the cultural variable (Larson, 1977).

Moreover, among the factors that developing countries must address to ensure their development and their integration into globalization, while taking into account cultural differences they have with other developed countries, there is accounting, and more generally the national accounting system.

At first glance, accounting and culture have only weak links. Or, accounting gives structure to society. Depending on the firm, accounting and accountants differ. Indeed, it is clear that accounting and accountants do not have the same role in society from one country to another. Today, even as the cultures tend to merge (known example of a Western culture), there are still differences between countries regarding their accounting. We talk about cultural accounting differences (Daske, Hail, Leuz, \& Verdi, 2007).

Moreover, the problem is that despite efforts made by international organizations working on the development and improvement of international accounting standards, it seems that the process of development and improvement does not take into account the specificities of emerging markets. 
As a reminder, an emerging country is defined as:

A developing country that has already overtaken some of the developed countries (e.g., the Asian newly industrialized countries: South Korea, Taiwan, Hong Kong, Singapore) or that appears on track to experience the same "success story" (China, India... to a lesser extent). Those are primarily the economies of Southeast Asia, the countries of Central and Eastern Europe and some Latin American countries, but also Turkey, South Africa... As there are no clear criteria, we often call "emerging countries" all developing countries with high growth, without further details. (Mucherie, 2008, p. 1)

Today, there is an extremely fast growing competence in several areas of emerging countries and a rise of firms from these countries in all sectors. Offshoring to emerging countries is no longer limited to the transfer of activities based on unskilled labor, they touch today: supporting services, design, research and development and especially accounting and finance. Thus, the emerging countries that want to promote the installation of foreign companies in the country are forced to adapt their protectionist policies and be opened to international reforms. In this case, these countries are increasingly interested in the adoption of international accounting standards.

Several studies focus on the adoption of IAS/IFRS in emerging countries. Chouchane (2008) established a review of these studies, distinguishing between those on a group of emerging countries and those that specifically address the case of a given emerging country.

Thus, Quinn (2004) classed studies on the relevance of international standards for emerging countries into two groups: studies performed on a group of emerging countries, including the studies of Larson (1993), Hassan (1998), and Hove (1990); and studies focused on the case of one given emerging country. These studies include those of Samuels and Oliga (1982) on the Egyptian case, Al-Rai and Dahmash (1998) in Jordan, Chamisa (2000) in Zimbabwe, Jaruga (1993) in Poland, Ashraf and Ghani (2005) in Pakistan, Tyrrall, Woodward, and Rakhimbekova (2007) in Kazakhstan, and Chouchane (2005) and Trabelsi (2010; 2013) in Tunisia. These studies have attempted to examine the specific economic and cultural environment in each country to determine the relevance of international accounting standards for each case.

For most of the cited studies, whether they are related to a group of countries, or to a particular country, the hypothesis that international accounting standards are an appropriate system that facilitates economic growth in emerging countries (Belkaoui, 1988) was empirically validated. However, this hypothesis is valid only for countries that have changed the IAS before adopting them to meet their environmental and local conditions. These results join the affirmation that international standards are not relevant for countries that do not adapt them to their cultural and economic contexts (Chouchane, 2008).

Also, it is clear from the literature that most of the countries called "emerging market countries" face serious obstacles to the implementation of international accounting standards and therefore wish to find an international solution to their accounting needs.

In fact, besides the universal obstacles for the adoption of international accounting system, it is clear that there are many challenges and constraints specific to emerging countries related to specific contextual characteristics to those countries. Moreover, we know that a growing economic uniformity, by its very nature, goes against the particularities of local specificities of each country, and therefore, in this case, the emerging countries.

Thus, in an interview with CGA Magazine in 2006, Pierre Barnes, a member of the Montreal's Certified Public Accountants, former president of Interamerican Accounting Association (IAA), draws an analogy between the situation of SMEs whose needs in accounting standards are very different from those of big firms, and that of emerging countries whose needs and concerns are quite different from those of developed countries, 
regarding accounting standards and international harmonization. This analogy was also established by the ISAR group that also showed the big difference between developed and emerging countries to explain the problem of international harmonization in emerging countries.

As a result, in the last few years, the debate around the adoption of IFRS by emerging countries has greatly refined, both in the field of professional accountants and in that of the research community in accounting.

In fact, according to Colin Fleming, project manager at the IASB and responsible for the development of international standards in countries with emerging markets, four conditions are essential for a given country to "convert" under IFRS, namely: "accounting standards, qualified and independent auditors and accountants, a strict independent and impartial regulatory authority, and a fair government system”. If one can easily confirm these conditions in developed countries, the situation in emerging countries is very different (Chouchane, 2005).

Indeed, developed countries have regulatory frameworks, skilled professionals, and a well-developed accounting infrastructure. For example, in France, the accounting profession has around 500,000 employees in all accounting organizations, including accounting firms and statutory auditors. This is one of the major professions in France by the workforce. This situation is also found in other Western countries, and is accompanied by more intellectual recognition, more social, more moral authority of accounting. The accounting studies in France, for example, have experienced the same expansion.

That said, the situation of the accounting discipline is different in emerging countries where the maturity of accounting for the expansion of knowledge and accounting education has just begun. Thus, several difficulties are faced in these countries. Today in emerging countries, it is easy to see that accounting is not a usual topic in the mainstream press, on television or radio, unlike developed countries where, in recent years, specialized journalists in some newspapers (Le Monde, Le Figaro, Les Echos, La Tribune, etc.) follow the profession and its developments.

Claire Egan, director of the technical training committee of International Federation of Accountants (IFAC), considers that in emerging markets, the development of the capacity of the profession, including skills, is a very important issue. The creation, development, and management of a professional body of accountants are essential to the creation of this capacity, in addition to the need to establish an appropriate regulatory framework to govern the accounting profession and adopt standards with a recognized quality. The implementation, monitoring, and enforcement of international standards can be problematic (Quinn, 2004).

Yet, it is clear that the accounting associations in emerging market countries and the governments of these countries do not have the resources to follow these recommendations. According to Paul Pacter, head of the IASB's project on SMEs, director at the central office of the "International Financial Reporting Standards" and managing partner at Deloitte Touche Tohmatsu in Hong Kong:

The accounting organizations from emerging economies have very little staff. They focus more on education, training and prospecting than on the implementation... But that's the nature of the emerging economies; they have many other concerns than the implementation of accounting standards.

Almost contradictorily to what Paul Pacter says, according to Claire Egan, the major concerns of emerging markets are the lack of a fundamental infrastructure for training that would allow students to meet international standards, the lack of expertise expected from professional accountants, and the lack of regional resources, that is to say, the human intellectual capital and the financial resources for the development of a quality training program that would be recognized internationally. This is often a problem in these countries (Quinn, 2004). 
Colin Fleming insists on the approximation by ISAR between the situation of emerging countries and SMEs, showing that both for SMEs than for emerging countries, the application of all IAS/IFRS violates the principle benefit/cost. Indeed, the application of these international standards requires human and material resources. Most emerging economic entities neither have the specialized staff nor the necessary technical infrastructure and the resources required to implement these standards (Chouchane, 2005). In other words, having not participated in the process of creating this international framework, and having not been represented at the choices and decisions in international standardization, emerging countries cannot logically have, at least immediately, accountants and professionals, perfectly able to understand and implement, without difficulty, international accounting standards.

In addition, all emerging entities do not see the direct interest of the adoption of international accounting standards. Instead of this, these entities, having usually a conservative accounting culture and characterized by a greater restriction of disclosure of accounting information in the new system, would see in the new system, known primarily by his call for financial transparency, the "informer" able to report their irregularities.

Moreover, sometimes the regulatory authorities of a country claim that they want to conform to international standards, as they are themselves changing the rules. In other words, standard-setters in many countries are trying to adopt the IAS/IFRS when drafting their national accounting standards. Yet, when you look more closely, many differences exist.

Also, the effort of the World Bank and IFAC interested in the concerns of emerging markets regarding international standards is an important first step in the right direction. However, although some emerging countries have decided to change their laws to incorporate the text of international standards in their corporate law, lack of infrastructure and qualified accountants makes it missing essential knowledge.

Finally, it is clear that in general, the developed and emerging countries respectively have a market economy and a bank-oriented economy. According to Durnev and Kim (2005), firms of bank-oriented economies disclose less their financial information. The explanation of Morris and Gray (2007) is based on the direct negotiations between the lender and the borrower, in which the second may provide any information requested directly to the lender. This results in reducing the public need for public disclosure of financial information. Conversely, for Morris and Gray (2007), more financial transparency is found in countries based on a market economy. Therefore, knowing that IFRS brought a culture that encourages financial transparency, we can deduce that the emerging countries are less likely than developed countries to implement IFRS.

For all these reasons, the actors responsible for accounting standard setting are facing, particularly in emerging countries, many difficulties, mostly cultural but also technical, about adopting the international standards.

This is a serious problem, because the lack of application of international standards in emerging countries is expensive for these countries in many ways.

First, when a company established in a country with an emerging market prepares and presents its financial statements under the local system of the country, it is not as trusted as a Canadian or American firm, which may have direct consequences like reluctance to investments in emerging markets.

Moreover, given that for some emerging market countries no date is set for adherence to international standards, investors can expect that the flow of international capital continues to be hampered, and the potential of bilateral agreements could be reduced (Quinn, 2004). 
In other words, if the emerging market countries do not stick or fail to join the unique international accounting system, everyone is likely to be penalized.

In conclusion, as Waitzer ${ }^{1}$ says, it is clear that having international standards is one thing, applying them by everyone is another thing. For example, according to Morris and Gray (2007), it is typical in some Asian countries to meet local standards based on IFRS that are associated with weak implementation.

Of course, this separation between emerging and developed countries regarding IFRS implementation is neither a strict nor a general rule. Besides, there are many developed countries that have not yet harmonized their financial and accounting systems with the international standards, while some emerging countries such as China and India took the step and made it very clear that they are in the process of adopting IFRS. The fact is that any change or reform cannot be done without difficulties and obstacles, and this is the case for both emerging and developed countries. In the next part of the paper, other factors for the reluctance to IFRS adoption are exposed.

\section{IFRS Would be Hard/Easy to Implement According to the Classification of the Country's Culture and Local Accounting System}

Each country is characterized by an accounting system that reflects its history, its economic and political system. That is the reason why literature has several classifications of accounting systems. The reviews conducted by Radebaugh and Gray (2002), Choi and Meek (2005), and Morris and Gray (2007) report classifications of accounting systems developed deductively or inductively, using various concepts from various fields such as law, economy, taxation, anthropology, and sociology.

Among the studies that show the diversity of accounting systems, we find the classification of Nobes (1983; 1992; 2004), putting the country's culture in the center of the differences between accounting systems, and the classification of Morris and Gray (2007) identifying in the literature five levels of accounting system classification related to the disclosure of the accounting and financial information. Those levels are the legal system of the country, the actual implementation of local standards based on IFRS, banking orientation of the economic system, the importance of the financial market in the national economy, and the cultural distance between the country and USA or UK.

Beyond these classifications, the best known, although criticized, is the classification of accounting systems in continental model and Anglo-Saxon model. It is to the latter that belongs the philosophy of the IFRS, with their historical and geographical origin.

In the following, after a presentation of the specificities of the two accounting models, we will see if the classification of a local accounting system in continental or Anglo-Saxon system has an impact on the implementation of IFRS in the country.

\section{Continental Model vs. Anglo-Saxon Model}

The two accounting models, related to their geographical origins or socio-political influences, present differences in the preparation and communication of accounting information.

The continental model characterized by a juridical regulation. Walton (2000) identified the premise of Continental Europe accounting in the 17th century in France. Despite its name, this continental model is not limited to the countries of the old continent, such as France, Germany, Belgium, Spain, etc., but it is also applied in other countries such as Tunisia (until 1996), Morocco, Algeria, Ivory Coast, Japan, etc..

\footnotetext{
${ }^{1}$ Edward Waitzer, chairman of Stikeman Elliott, and adviser of the Committee on Values and Insurance of Chile.
} 
Continental accounting countries are characterized by a codified legal system, such as the French Napoleonic codes, where the laws are presented in detail, excluding any possibility of interpretation. This is also the case of the accounting law, governed by a body of fixed and rigid accounting rules. Presented in this way, such a system is related more to the legal appearance than to the economic reality. Moreover, in the continental model, accounting practices tend to be harmonized with the tax rules that allow the best reduction in the tax base, resulting in a misrepresentation of the economic reality of the entity.

The progressive use of accounting as evidence, information and calculation of the tax base required regulatory legitimacy of its rules. Thus, the commercial codes, civil codes, and general accounting plans adopted by most countries belonging to the continental model (Lefebvre, 1999) appeared. In fact, the history of the creation of the accounting plan was summarized by Degos and Mattessich (2003) through a review of the French accounting literature covering the first half of the 20th century. This review of the literature shows that accounting has evolved from the late 19th century, especially after the Second World War, with the advent of the accounting plan, which quickly became the main accounting instrument of national institutions (Degos, 1998).

The study of Degos and Mattessich (2003) shows that the attempts to create a form of accounting plan date back to the 1890s in Belgium, when a first proposal was studied by the Accounting Academic Society of Brussels (Gomberg, 1929). Later, the Belgian Otlet (1901) offered a four-part universal classification scheme of accounts and the French Faure (1905) attempted to develop a plan of accounts (Richard, 2000).

That said, the first modern reflections on the synoptic tables of accounts are emitted by the French Batardon (1911) and the German Schär (1911). Also, one can also cite Blairon (1926), another Belgian who has worked on a basic plan of accounts. According to Degos and Mattessich (2003), as "organic document allowing state institutions to standardize and structure the accounts", the accounting plan would be a Soviet invention of the 20s, which was taken by the Germans, who founded a Committee in 1921. At the end of work of this committee, the 1927 accounting plan was born. This plan, appropriate to a war economy and imposed by the Nazis to economic entities at the chambers of commerce, reached seven successive editions before being replaced in November 1937 by Goering plan applied in 1939.

If we consider the French example, it is noted that although it was spoken in 1938 about an accounting plan for insurance companies, it was only four years later that the "Inter-ministerial Commission of Accounts" instituted in 1941 by the Vichy regime and chaired by Jacques Chezleprêtre ${ }^{2}$, assisted by Auguste Detoeuf ${ }^{3}$, produced the French Accounting Plan of 1942 (Degos \& Mattessich, 2003).

Moreover, among the objectives of the accounting plan cited by Detoeuf (1941), one can find the typical goals of a continental accounting ideology where accounting is simply a tool of the state allowing it to exercise controls at different levels of the economic activity. Thus, the 1942 plan is basically supposed to allow an accurate calculation of the average costs of certain types of product, in order to allow the government to have a better price control. It should also reduce the tax evasion opportunities by increasing the clarity of accounts. Finally, the French plan of 1942 was designed to prevent the government from committing errors in the calculation of taxes and the development of economic policy by normalizing each industry account.

\footnotetext{
2 Jacques Chezleprêtre, Director of Economic Documentation, already the author of an attempt to accounting plan in 1940.

3 Auguste Detoeuf, Vice President of the Inter-ministerial Commission of Accounts.
} 
Moreover, the same type of goals is also found, according to Degos and Mattessich (2003), in the new post-war accounting plan introduced in 1947. Indeed, like its predecessor of 1942, the 1947 plan aimed mainly at the state control of economic activities, including prices control, competition, government subsidies, transport policy, the customs, social policy, and the improvement of productivity (Brunet, 1947; 1951).

Finally, with its 1957 version, as well as the one amended in 1982, slightly retouched in 1986 and rewritten in 1999 to strictly comply with the legislation of the EU (Degos, 2000), the French accounting plan has always maintained the mark of the first attempt in 1942, a Continental mark, making accounting a special tool to government service to control the different economic levels, political or social of the country.

Therefore, for these countries such as France, Belgium, or Germany belonging to the continental model, accounting standards-setting is the sole responsibility of the state, through public agencies, providing to professional and private organizations, if available, an advisory secondary role. For example, in France, the accounting regulatory authority was granted to the Accounting Regulation Committee, assisted by a second public body, the National Accounting Council, which provided an advisory role. Both were merged in 2009, resulting in a new government agency, the Authority Accounting Standards, now in charge of the accounting regulations in France.

Moreover, although having no conceptual framework formalizing the objectives and basic principles of accounting, the continental model contains some implicit or explicit principles. An example is the precautionary principle, which banishes any accounting maneuver that could lead to an overestimation of the results of a company and this in order to protect the company's creditors. According to Colasse (1996), the idea is not to systematically underestimate the assets of the company, but to avoid over estimate. Also, the continental accounting is governed by the principle of continuity of operations, in which the company is presumed active in the near future, with neither the intention nor the obligation to go into liquidation and reduce significantly short-term activities. This presumption is used to evaluate the wealth of the company, referring to the economic reality and not a possible asset value (Boussard, 1997). Another example of accounting principle related to the continental model, the principle of consistency of methods requires that the choice of the presentation of the financial statements and the valuation methods used must be maintained from one accounting period to the next, unless an exceptional change in the commercial situation occurs, in which case any changes must be notified and justified in the notes (Boussard, 1997).

Thus, these principles related to the continental model induce accounting practices and financial reporting particularly conservative. They primarily seek compliance with government policies and the protection of creditors of the company provided by the observation of the precautionary principle that overrides the "true-and-fair-view" principle.

To conclude, we can say that in the continental model, the main function of accounting is to provide evidence in accordance with legal requirements, while satisfying various needs from tax authorities, administrative agencies, investors, creditors, employees, etc. (Ding, Stolowy, \& Tenenhaus, 2001; 2002). This model is used by the EU, which makes accounting regulations one of the pieces of legislation on companies through Article 54, Paragraph 3.g of the Treaty of Rome (Evraert \& Prat dit Hauret, 1996).

The Anglo-Saxon model characterized by an accounting system with a conceptual framework. Appeared in the 19th century with the industrial revolution, the Anglo-American accounting model, commonly called “Anglo-Saxon” (Walton, 2000), is particularly applicable in Anglo-American countries and almost all commonwealth countries. 
The Anglo-Saxon countries are countries based on a common law system, where the use of case law, custom, and practice is fundamental. In these countries, the laws do not provide strict rules, but general principles, giving the judges a wide margin of interpretation. This also applies to Anglo-Saxon accounting standard-setting, which is mainly based on accounting principles and a conceptual framework for the preparation and publication of the summary financial statements.

Colasse (2000) defined the conceptual framework as a coherent system of fundamental objectives and principles related, likely to lead to robust standards and indicate the nature, role, and limits of financial accounting and financial states. This definition of the conceptual framework shows the importance of the principles underlying the Anglo-Saxon accounting law, which should be followed while demonstrating an ability to interpret and adapt to specific cases. Among these principles, we cite, for example, the concept of the "true-and-fair-view" principle, which encourages the presentation of the reality of the financial situation of an economic entity, even allowing the exemption to professional bodies' recommendations if this allows a better translation of economic reality.

In the same spirit as "true-and-fair-view", the principle of "substance over form" governs the accounting of contracts and the presentation of financial statements of the company in Anglo-Saxon accounting. Thus, according to this principle, all the company's life events are considered objectively in accordance with their substance and financial reality without considering only their legal appearance (Binet, 1991).

The peculiarity of this Anglo-Saxon accounting culture results from the economic nature of the countries that adopt it. They are precisely oriented towards a so-called "market" economy. The entities of these countries are financed mainly in the financial markets, characterized by their great development. Therefore, the accounting and financial information published by economic entities is primarily oriented towards investors who are interested in the company's financial performance to assess the profitability of their investment. Therefore, to attract investors and raise funds in the capital markets, the Anglo-Saxon firms should publish objective and credible financial information, reflecting a true picture of the entity. Only a high-quality accounting system enables the production of such accounting and financial information presented especially in the financial statements and responding primarily to the demands of investors and the stock market authorities. In this regard, Ding et al. (2001; 2002) explained that in Anglo-American countries, the role of accounting is more to disseminate economic information of the company to the outside in a context where the ownership and the management are separated for most companies. The accounting information consists of a report produced by the company's managers to the owners of the company, which are none other than investors.

Furthermore, in Anglo-Saxon countries, the accounting standardization process is quite independent of the power of the state, independence illustrated, for example, by the distance that exists in this type of accounting model between accounting and taxation.

In fact, the Anglo-Saxon standardization is mainly based on professional judgment, hence the rise in the countries of powerful and autonomous associations with assignments production and revision of local accounting standards, for example, the $\mathrm{US} \mathrm{FASB}^{4}$, or the $\mathrm{ASB}^{5}$ in Britain, which replaced the $\mathrm{ASC}^{6}$ on August 1, 1990 (Langot, 1997).

\footnotetext{
${ }^{4}$ FASB: Financial Accounting Standards Board.

5 ASB: Accounting Standards Board.

${ }^{6}$ ASC: Accounting Standards Committee.
} 
Nevertheless, there is a limit of categorizing countries according to the Anglo-Saxon model, as this can lead to an abusive group of countries that have not much in common except the English character (Evraert \& Trebucq, 2002). Indeed, as shown by the studies of D'Arcy (2001) and Needles and Stevens (2002), far from being homogeneous, the Anglo-Saxon countries are characterized today by the heterogeneity of their rules, making incoherent any study involving these countries in the same basket.

Thus, continental accounting and Anglo-Saxon accounting vary at more than one level, including the destination of the information produced. According to Haller and Walton (1997), in Continental Europe, accounting can be seen as facing all partners (stakeholders) of the company, while in the Anglo-Saxon countries, it only follows the perspective of shareholders. This idea is also affirmed by Ball, Kothari, and Robin (2000). Now, given that the accounting information varies depending on the users to whom it is intended, this explains the difference between the two accounting models: Continental and Anglo-Saxon (Evraert \& Trebucq, 2002).

\section{Harmonization Towards a Single Accounting Anglo-Saxon Culture}

The five cultural dimensions of Hofstede (1980) and G. Hofstede and G. J. Hofstede (2005) applied in accounting by Gray (1988) produced a set of analytical and empirical works in international accounting. Doupnik and Tsakumis (2004) provided a recent review of this literature, showing the Anglo-Saxon accounting guideline of the IFRS. This approach has been criticized by Taylor (1987) since it would make IFRS less suited to countries without Anglo-American cultural dominance. Morris and Gray (2007), therefore, believed that the less the country is culturally linked to USA, the less it would be likely to adopt IFRS.

Conversely, other authors approve the Anglo-Saxon cultural dominance of IFRS, claiming that of the two models, continental and Anglo-Saxon, the second best fits the current economy, allowing better financial and accounting information. Understanding the changes introduced in an accounting system requires to define the concept of "culture" in the accounting literature and examine the impact of the dominating Anglo-Saxon culture of IFRS, so as to see if they will remove national identities by "Americanizing" accounting in the world, or whether they actually allow an improvement in the quality of accounting and financial information.

Definitions of accounting culture. The concept of culture has been recognized in the accounting literature by Hofstede (1980, p. 5). According to this author, culture is a "collective phenomenon shared by people living or having lived in the same social environment where the culture was acquired. This is the collective mental programming which distinguishes the members of such a group or class of persons". Hofstede (1980) identified four cultural dimensions that underlie the diverse cultural settings from one environment to another. These dimensions are power distance (PDI), individualism versus collectivism (IDV), masculinity versus femininity (MAS), and uncertainty avoidance (UAI).

These values determined by Hofstede show the diversity of cultural settings. So they inspired the accounting researchers to apply them to what may appear as a cultural construct: accounting systems (Azan, 2000).

At the head of these researchers, we find Gray (1988), which attempted to establish a correlation table between the cultural variables of Hofstede (1980) and certain accounting practices, to analyze the accounting systems. 
For Belkaoui (1995), culture shapes the accounting systems. To demonstrate that, the author established a typology of culture from the literature. First, culture is defined as an instrument in a functionalist vision. This would be a response to physical and psychological needs. The perception of accounting differs from one country to another and from one culture to another. It is seen as an independent system with a social purpose. Second, the culture is defined as an accommodation and a fit that connects individuals. Accounting is, therefore, closely linked to the environment in which it operates. Third, it is a learning and sharing system of rules and knowledge. Accounting would, therefore, be a shared system of rules established by individuals. Fourth, culture is the expression of shared symbols and concepts. This is the reason why the accounting system is considered as a language that varies from one country to another. Culture is finally defined in the literature as the expression of a structure or infrastructure. From this point of view, accounting thus forms an unconscious process, resulting in a consistent set of accounting rules.

The relation between the classification of the country's local accounting system and the ability to implement IFRS. The diversity of accounting systems is important and comes from the very definition of the word "culture". However, paradoxically, according to Azan (2000), culture is also a factor of stability and permanence of accounting systems, to the extent that it is the expression of shared symbols and concepts.

According to the meaning that we give to the concept of culture, the apprehension of an accounting system differs. However, as stated by Azan (2000), very few models are able to perceive changes in accounting frameworks.

However, IFRS diffuse Anglo-Saxon accounting vision. In other words, international accounting harmonization is largely inspired by the Anglo-American accounting model (Ding et al., 2001; 2002).

Therefore, a question arises about the risks of incompatibility of IFRS to local identities of countries initially carrying a continental accounting model.

At first, the process of international accounting harmonization has not been easy. Indeed, political, cultural, and sociological brakes prevented rapprochement between standard setters from countries with Anglo-American accounting model with a conceptual framework, and standard setters with geographical or cultural origins from Continental Europe, governed by the continental accounting model, with an accounting plan.

Consequently, the first form of international reference was not quite successful. Some argue that it is only based on the American conceptual framework developed by the FASB between 1973 and 1985, that the international standardization process began to show results, especially with the publication by the IASC in 1989 of the conceptual framework for the preparation and publication of financial statements, a framework closely inspired by the US FASB recommendations.

Incidentally, during an interview with A. Mabkhout ${ }^{7}$ in 2004, the latter said that today, globalization is anything but the internationalization of the American conception of the economy, investment, and financing business, notably marked by an Anglo-American influence in international accounting standards-setting. According to A. Mabkhout, a correlation exists between the area of the economy and the financial accounting.

\footnotetext{
${ }^{7}$ A. Mabkhout, Professor of Accounting Theory and compared international standards, institutional and financial consultant for international organizations (World Bank, FAO, ...), partner of PricewaterhouseCoopers (PwC) Tunisia, and the first official in charge of the Corporate Reporting Group (CRG) who wrote the book, leading the accounting reform project in Tunisia (1995/1996) conducted by PwC on behalf of the Tunisian National Accounting Council.
} 
American principles which inspire IFRS to revolve around a conceptual framework and are fundamentally different from the accounting plan model turned to tax and legal considerations, originally created and applied in countries such as those in Continental Europe that relied, mainly, always on bank funding and government support for the creation and development of enterprises. Moreover, due to the US accounting culture characterizing international standards, according to Evraert and Trebucq (2002), many European companies bet for a future alignment of international rules on those of the US, and took advantage of their overseas listing to be close or simply adopt US GAAP to prepare the adoption of IFRS.

However, several researchers disagree with the quality of accounting information disclosed in accordance with US accounting principles (US GAAP) and therefore IFRS, for non-US companies. For example, Alford, Jones, Leftwich, and Zmijewski (1993) found that the accounting results prepared in accordance with local standards in Australia, France, the Netherlands, and the UK were faster to build and more relevant in terms of supply of information than those prepared in accordance with US GAAP (Ding et al., 2001; 2002).

The fact is that the transition to IFRS could not be without difficulty for countries that adhere to it. Moreover, given that the international accounting standards come with an Anglo-Saxon tradition, the reform for adopting these standards is even more complicated for countries that are initially impregnated with a continental accounting culture, where changes in IFRS would be even more difficult to assimilate.

Paradoxically, especially businesses in Continental Europe and Asia need an Anglo-American accounting reference in order to get into foreign financial markets (Ding et al., 2001; 2002). Moreover, according to Walton (1996) and Bernheim (2000), international accounting for large enterprises should be the Anglo-American accounting model because they need an accounting system adapted to the financial markets. In other words, Ding et al. (2001; 2002) explained that the dominance of Anglo-American financial markets and the increased presence of Anglo-American institutional investors in European stock exchanges are a logical consequence that the Anglo-American model extends and becomes a reference for large companies from Continental Europe. Therefore, although contested by some, several studies emphasized the supremacy of the Anglo-American model in terms of the quality of the accounting information it produces (Ding et al., 2001; 2002). Thus, the adoption of an Anglo-Saxon conceptual framework, addressed primarily to the needs of investors, is regarded as a panacea for many (Gumb, 2004). According to Pourtier (2004), the financial information available on the Anglo-Saxon financial markets have a stronger reputation than the European markets and this is because of the accounting culture and the "credo" that such financial information have. Moreover, according to the same author, international accounting and financial framework is a more demanding framework for information density and quality than the accounting officers of the European countries (Pourtier, 2004). This is confirmed by Ding et al. (2001; 2002) that compared, at several levels, the accounting presentation regulated by the Anglo-Saxon and continental accounting models. For example, balance sheet and presentation of the income statement in the Anglo-American model is relatively simple, but the focus will be on a detailed presentation of the annexed information. This is due to the nature of the common law system which characterizes the Anglo-American world. In contrast, in Continental Europe, the balance sheet models and income statement, often defined by national accounting regulations, contain detailed elements at the expense of the importance attached to the annex, and this despite the recognition, by most continental countries $^{8}$, of the essential role of this document. In this sense, Colasse (1995) defined the Annex as a way to

${ }^{8}$ 4th and 7th European directives (1978, 1983). 
overcome (and some time to transgress) the patrimonial model to provide information beyond the latter but which may be particularly important from an economic point of view. It is somehow a step towards accounting rule of the substance over form, an Anglo-Saxon principle.

This often leads to a de jure adoption of IFRS, not followed by a de facto integration, to display an "IFRS label" within the meaning of Daske et al. (2007).

In fact, by preparing in 2004 the IFRS adoption in the EU starting from 2005 for the consolidated accounts of listed companies, Chouchane (2005) evoked the result of a long way towards harmonization of accounting and financial communications practices. Thus, according to the same author, in the French case, a country with continental accounting tradition, alignment with IFRS is much more than a harmonization, but also "a framework more demanding for information density, and with more broadcasts quality than the French regulatory framework... in this perspective, a number of more or less discretionary financial publications, and rarely comparable, could disappear under the weight of a put to binding standards”.

Moreover, as an example of interpretation of Gray's (1988) model, a society characterized by a high degree of uncertainty and low levels of individualism and masculinity has an accounting system characterized by a high degree of conservatism. Azan (2000) confirmed this interpretation of the Gray's table. According to this author, a country characterized by an aversion to uncertainty, with a high degree of uniformity, a strong distance to power, and a moderate degree of individualism has a conservative accounting system, based on the social status and taking into account the views of professionals (Azan, 2000). According to Baydoun and Willett (1995), this description corresponds perfectly to the French case.

For this, especially for countries initially covered by a continental accounting culture, the approach of the international harmonization begins with an adaptation to the Anglo-Saxon accounting culture, which is different from the continental accounting culture at many levels. So, achieving such a transition requires for a country to develop its local system. Such a process can be long and complicated, leading to many cultural, economic, and institutional changes of the local context.

Finally, it is noted that although it constitutes a theoretical reference for different accounting research, the ability of the model of Gray (1988) to fully explain the nature of accounting frameworks is questionable. For Azan (2000), the financial "reporting" can result not only from cultural trends, but it is also subject to various contingencies and influences. These influences can be found, for example, by observing the case of Arab countries regarding the accounting principles and practices. Thus, a series of Arab countries, including Egypt, Saudi Arabia, and the United Arab Emirates, use accounting systems closer to the French system (Kantor, Roberts, \& Salter, 1995) than the German or Anglo-Saxon ones (Azan, 2000).

Thus, in view of the various financial reporting in Western countries (France, UK, USA), Azan (2000) found that the country, whose accounting system has the most in common with the accounting systems of the Arab countries compared to the Anglo-Saxon countries, is France.

\section{Conclusion}

This paper attempts to show some of the difficulties faced by emerging markets compared to developed countries, for the adoption and implementation of IFRS.

The literature shows that emerging countries do not have the infrastructure or the real needs justifying a reform of international harmonization, except the need to display an IFRS label (Daske et al., 2007), to facilitate the access of companies from emerging economies to developed financial markets. 
Moreover, the Anglo-American culture attached to IFRS leads to a difficulty in adopting those standards by any country whose original accounting system is continental. Indeed, for these countries, the process of international harmonization begins with an adaptation to the Anglo-Saxon accounting culture, the latter being different from the continental accounting culture at several levels.

According to Rey (2003), Europeans can meet this difficulty by speaking with one voice to negotiate and form a counterbalance about international standardization. This is not the case for emerging countries.

Thus, the phenomenon of financial globalization appears as a process by which the developed countries, with Anglo-Saxon and continental accounting models, impose their rules with lobbying on international accounting standards bodies, to control accounting, this “common language of capitalism” (Véron, Autret, \& Galichon, 2004).

However, we should not ignore the interest of the principle of international accounting harmonization, and therefore the alignment of national accounting systems on a single accounting system. Thus, the efforts of international accounting harmonization taken by many countries are seen as a step towards a better quality of financial "reporting” and more financial transparency.

\section{References}

Alford, A., Jones, J., Leftwich, R., \& Zmijewski, M. (1993). The relative informativeness of accounting disclosures in different countries. Journal of Accounting Research, 31, 183-223.

Al-Rai, Z. K., \& Dahmash, N. (1998). The effects of applying international accounting and auditing standards to the accounting profession in Jordan. Advances in International Accounting, 1, 179-193.

Ashraf, J., \& Ghani, W. (2005). Accounting development in Pakistan. International Journal of Accounting, 40(2), 175-201.

Azan, W. (2000). Systèmes comptables, évolution et déterminants: le renforcement du contrôle externe en Allemagne par le biais de la KontraG. Colloque de l'AFC, Angers.

Ball, R., Kothari, S. P., \& Robin, A. (2000). The effect of international institutional factors on properties of accounting earnings. Journal of Accounting and Economics, 29(1), 1-51.

Batardon, L. (1911). La tenue des livres sur feuillets mobiles. Publications de la société académique de comptabilité (2nd ed.). Paris.

Baydoun, N., \& Willett, R. (1995). Cultural relevance of western accounting systems to developing countries. Abacus, 31(1), 67-92.

Belkaoui, A. R. (1988). The new environment in international accounting: Issues and practices. New York, NY: Quorum Books.

Belkaoui, A. R. (1995). The cultural shaping of accounting. London: Quorum Books.

Bernheim, Y. (2000). Pour des normes comptables européennes? Les Échos, 10 février.

Binet, L. (1991). Les états financiers anglo-saxons: Comparaison avec les états financiers français dans le cadre de l'harmonisation internationale. Economica.

Blairon, H. (1926). Cours complet de comptabililté des industries manufacturières. Bruxelles.

Boussard, D. (1997). La modélisation comptable en question (s). Economica.

Brunet, A. T. (1947). Rapport général présenté au nom de la commission de normalisation des comptabilités. Paris: Imprimerie Nationale.

Brunet, A. T. (1951). La normalisation comptable au service de l'entreprise, de la science et de la nation. Paris: Dunod.

Chamisa, E. E. (2000). The relevance and observance of the IASC standards in developing countries and the particular case of Zimbabwe. The International Journal of Accounting, 35(2), 267-286.

Choi, F. D. S., \& Meek, G. K. (2005). International accounting (5th ed.). Upper Saddle River, NJ: Pearson Education.

Chouchane, B. (2005). Vers un cadre de comptabilité et d'informations financières différentielles pour les PME tunisiennes. Paper presented at the 3rd International Conference of Finance, Hammamet, Tunisia.

Chouchane, B. (2008). Pertinence des normes comptables IAS/IFRS aux PVD: le cas de la Tunisie. Les normes comptables internationales IAS/IFRS, Evolution et Application, Univ. M. Mammeri, Tizi-Ouzou, Algérie. 
Colasse, B. (1995). 25 ans de comptabilité générale... Une nouvelle naissance de la vieille discipline? Vingt ans de recherche à Dauphine, Masson, Paris, pp. 23-38.

Colasse, B. (1996). La comptabilité générale. Economica.

Colasse, B. (2000). Cadres comptables conceptuels. In Encyclopédie de comptabilité, contrôle de gestion et audit (pp. 93-104). Economica.

D’Arcy, A. (2001). Accounting classification and the international harmonization debate: An empirical investigation. Accounting, Organizations and Society, 26(4-5), 327-349.

Daske, H., Hail, L., Leuz, C., \& Verdi, R. (2007). Adopting a label: Heterogeneity in the economic consequences of IFRS adoptions. 30ème congrès annuel de l'EAA, Lisbonne, Portugal.

Degos, J. G. (1998). Histoire de la comptabilité. Paris: Presses universitaires de France.

Degos, J. G. (2000). Plan comptable: une réforme bienvenue et bien conçue. Paris: La Revue du Financier.

Degos, J. G., \& Mattessich, R. (2003). La littérature comptable francophone (1900-1950) et les risques d'une période chaotique. Cahier électroniques du CRECCI-IAE, numéro 05, Institut d’Administration des Entreprises, Université Montesquieu, Bordeaux IV.

Detoeuf, A. (1941). Exposé sur le plan comptable. Paris: Centre d'information interprofessionelle.

Ding, Y., Stolowy, H., \& Tenenhaus, M. (2001). The internationalization of financial statements presentation: An empirical study of French groups. Paper presented at the 24th Annual Congress of the European Accounting Association, Athens, Greece, April 18-20, 2001.

Ding, Y., Stolowy, H., \& Tenenhaus, M. (2002). L’internationalisation de la présentation des états financiers des sociétés françaises: une étude empirique longitudinale. Comptabilité Contrôle Audit, 1(8), 45-68.

Doupnik, T. S., \& Tsakumis, G. T. (2004). A critical review of tests of Gray's theory of cultural relevance and suggestions for future research. Journal of Accounting Literature, 23, 1-48.

Durnev, A., \& Kim, E. H. (2005). To steal or not to steal: Firm attributes, legal environment, and valuation. The Journal of Finance, 60(3), 1461-1493.

Evraert, S., \& Prat dit Hauret, C. (1996). Comptabilité financière. Paris: Vuibert.

Evraert, S., \& Trebucq, S. (2002). Une analyse quantitative des différences de mesures comptables dans les contextes français et américain. Cahiers électroniques du CRECCI - IAE, Cahier 02.

Faure, G. (1905). Traité de comptabilité générale. Paris: Masson.

Fouda, M. (2006). Différences culturelles et relations d'affaires entre pays d'Afrique et pays émergents d'Asie. Revue Française de Gestion, 2006/8, No. 167, ABI/INFORM Global, p. 65.

Gomberg, L. (1929). Histoire critique de la théorie des comptes. Weiss, Genève et Berlin.

Gray, S. J. (1988). Towards a theory of cultural influence on the development of accounting systems internationally. Abacus, 24(1), 1-15.

Gumb, B. (2004). Le management entre les logiques spectaculaires et anti-spectaculaires: vers une lecture situationniste de l'histoire de la comptabilité. Comptabilité Contrôle Audit, 3(10), 89-104.

Haller, A., \& Walton, P. (1997). Différences nationales et harmonisation comptable. In Comptabilité internationale (pp. 1-32). Paris: Vuibert.

Hassan, N. A. (1998). The impact of socio-economic and political environment on accounting systems preferences in developing economies. Advances in International Accounting.

Hofstede, G. (1980). Culture's consequences: International differences in work-related values. Beverly Hills, CA: Sage Publications.

Hofstede, G., \& Hofstede, G. J. (2005). Cultures and organizations: Software of the mind (2nd ed.). New York, NY: McGraw-Hill.

Hove, M. R. (1990). The Anglo-American influence on international accounting standards: The case of the disclosure standards of the International Accounting Standards Committee. In R. S. O. Wallace, J. M. Samuels, \& R. J. Briston (Eds.), Research in third world accounting (Vol. 1, pp. 55-66). Emerald Group Publishing Limited.

Jaruga, A. (1993). Changing rules of accounting in Poland. European Accounting Review, 2(1), 115-126.

Kantor, J., Roberts, C. B., \& Salter, S. B. (1995). Financial reporting practices in selected Arab countries: An empirical study of Egypt, Saudi Arabia, and the United Arab Emirates. International Studies of Management \& Organization, 25(3), 31-50.

Langot, J. (1997). Comptabilité anglo-saxonne: normes, mécanismes et documents financiers. Paris: Economica.

Larson, M. S. (1977). The rise of professionalism: A sociological analysis. Berkeley: University of California Press. 
Larson, R. K. (1993). International accounting standards and economic growth. An empirical investigation of their relationship in Africa. In Research in third world accounting: A research annual (Vol. 2, pp. 27-43). London.

Lefebvre, F. (1999). Mémento pratique: Comptable 2000. Edition Lefebvre.

Morris, R., \& Gray, S. (2007). Determinants of corporate financial transparency in Asian countries: The impact of country-level factors. 30ème congrès annuel de l'EAA, Lisbonne, Portugal.

Mucherie, M. (2008). Pays émergents. Le site des sciences économiques et sociales. Retrieved from http://www.melchior.fr/

Needles, B. E., \& Stevens, K. (2002). What should the IASB's agenda be? Implications of GAAP 2000. 25ème congrès annuel de l'EAA, Copenhague, Danemark.

Nobes, C. W. (1983). A judgemental international classification of financial reporting practices. Journal of Business Finance \& Accounting, 10(1), 1-19.

Nobes, C. W. (1992). International classification of financial reporting (2nd ed.). London: Routledge.

Nobes, C. W. (2004). Developments in the international harmonization of accounting (p. 448). New Library of International Accounting Series. Cheltenham: Edward Elgar Publishing.

Otlet, P. (1901). La classification rationnelle des comptes et le schéma universel de comptabilité. Bulletin de l’Institut International de Bibliographie, Fascicules 1-3.

Pourtier, F. (2004). La publication d'informations financières volontaires: un essai de synthèse. Cahiers électroniques du CRECCI, IAE, Cahier 08.

Quinn, L. R. (2004). Crise de confiance. CA Magazine.

Radebaugh, L. H., \& Gray, S. J. (2002). International accounting and multinational enterprises (5th ed.). New York, NY: John Wiley \& Sons.

Rey, H. (2003). La Mondialisation Financière. Conférence de l’Université de tous les savoirs.

Richard, J. (2000). Plans comptables. Encyclopédie de comptabilité, contrôle de gestion et Audit, Economica, Paris.

Samuels, J. M., \& Oliga, J. C. (1982). Accounting standards in developing countries. International Journal of Accounting Education and Research, 18(1), 69-88.

Schär, J. F. (1911). Buchhaltung und Bilanz (Bookkeeping and balance sheet). Berlin: Springer Verlag.

Taylor, S. L. (1987). International accounting standards: An alternative rationale. Abacus, 23(2), 157-170.

Trabelsi, R. (2010). Evaluating international accounting harmonization in an emerging country. Journal of Accounting and Management Information Systems, 9(3), 354-378.

Trabelsi, R. (2013). Towards a platform for evaluating the relevance of IFRS in a prior-implementation context. International Journal of Innovation and Applied Studies, 3(3), 626-650.

Tyrrall, D., Woodward, D., \& Rakhimbekova, A. (2007). The relevance of International Financial Reporting Standards to a developing country: Evidence from Kazakhstan. The International Journal of Accounting, 42(1), 82-110.

Véron, N., Autret, M., \& Galichon, A. (2004). L'information financière en crise: Comptabilité et capitalisme. Odile Jacob.

Walton, P. (1996). La comptabilité anglo-saxonne. Paris: Éditions La Découverte.

Walton, P. (2000). La Comptabilité en Grande-Bretagne. Encyclopédie de comptabilité de contrôle de gestion et d'audit, Economica, pp. 319-331. 